\title{
VISITOR SATISFACTION ATTENDING FESTIVAL IN BALI: CASE OF SANUR VILLAGE FESTIVAL 2018
}

\author{
I Gusti Ayu Dewi Hendriyani. \\ Sekolah Tinggi Pariwisata Nusa Dua Bali \\ Dewi.hendriyani2@gmail.com
}

\begin{abstract}
Festivals or special events have been one of the fastest developing tourism attractions in many countries. Bali as tourism destination have many activities on tourism event such as festivals or special events to attract more tourists to come every year. Sanur Village Festival (SVF) declared by the government as one of the top ten national tourism event in Indonesia. SVF is an annual event since 2006. Its community event founded by Sanur Development Foundation (YPS) which is a combination of several large-scale activities involving food festival, creative economy exhibition, various contests and competitions, art and cultural attractions, music as well as various types of environmentally-friendly activities. Quality of activities and service on an event is dynamic conditions that relate to fullfill the visitors expectation. In tourism event, quality of activities and service becomes success parameter as indication of satisfaction. The aim of these research is to know the visitors satisfaction attending festival in Bali, case study of SVF 2018. Sample of the research is visitors of SVF 2018 during period 22-26 August 2018 with total 135 respondents. The method of this research is quantitative method with analysis factor confirmatory using SPSS. Using teory from Crompton (2003) there are six factors and twenty six variables that were observed. The factors and variables are convenience value (F1) through five variables, service value (F2) through six variabels, perceived price (F3) through four variables, aesthetic value (F4) through four variables, playful value (F5) through four variables and social value (F5) through three variables. Finding in this research about visitors satisfaction attending festival in Bali, case of SVF 2018 is in good condition according to the guest overall comments. The leading factor and variable are playfull value (F5) and X21 (enjoyable). The strategic implication that should be done by management of SVF or Sanur Development Foundation to the result of reserach is to maintain what has been good and improve which one is unfavourable by make evaluation and standarization of work for all vendors/ suppliers that supported the festival.
\end{abstract}

Keywords : Visitor, Festival, Special Event, Satisfaction. 


\section{INTRODUCTION}

Bali is a province in Indonesia. Bali is also one of the islands in the Nusa Tenggara Islands. At the beginning of Indonesia's independence, the island was included in the Lesser Sunda Province with thousands of cities in Singaraja, and is now divided into 3 provinces, namely Bali, West Nusa Tenggara, and East Nusa Tenggara. In addition to consist of Bali Island, Bali Province region also consists of smaller islands in the vicinity, namely Nusa Penida Island, Nusa Lembongan Island, Nusa Ceningan Island, Serangan Island, and Menjangan Island. Geographically, Bali is located between Java and Lombok. The majority of the population of Bali is the leader of Hinduism. In the world, Bali is well-known as a tourism destination with the uniqueness of various arts and crafts. Bali is also known as the Island of the Gods and the Thousand Islands.

According to the Bali Provincial Statistics Agency (BPS:2018) data on foreign tourist arrivals to Bali Province for the January-June 2018 period has reached 2,893,005 people. If this figure is compared with the January-June 2017 period of 2,811,289 people visiting foreign tourists, there is an increase of $2.91 \%$. Distribution of foreign tourist arrivals to Bali through the airport is 2,856,728 people and through the port is 36,277 people. Judging from the nationality, the highest figure achieved by China was 677,212 people, followed by Australia at 544,877 people, then India amounting to 194,634 people, the rest from England, the United States, Japan, Malaysia, Europe, Singapore and others. The target of tourist visits to Bali in 2018 is for foreign tourists amounting to 6,000,000 people and for Indonesian tourists as big as 15,000,000 people

The city of Denpasar is the provincial capital of Bali. Denpasar City has 36 tourist destinations. Tourist destinations in Denpasar city consist of 3 museums, 4 parks, 1 cultural village, 11 temples, 4 markets, 1 monument, 8 beaches, 1 river, 1 monument, 1 subak, and 1 statue. One of the famous beaches in the city of Denpasar is Sanur Beach which is located in the village of Sanur, District of South Denpasar, Denpasar City. This beach is located in the East and South of Sanur Village, which is the edge of the Indonesian Ocean south of Bali Island. Sanur Beach is also known as Sunrise Beach. Because of its location in the east of the island of Bali, Sanur beach is the right location to enjoy the sunrise or sunrise. This makes this tourist spot even more interesting, there is even a segment on Sanur Beach called Mahari Terbit Beach because the scenery at the rising sun is very beautiful when viewed from there. Some of these coastal areas have exotic white sand. This natural beauty makes Sanur beach become a beach or natural tourist attraction that is so exotic and famous on the island of Bali.

Festival / event is an effective way to promote a tourism area / destination which will ultimately lead to improving the welfare of the community as well as increasing tourist visits. A festival or event has multiple direct and indirect benefits, including: 1). Introducing destinations, through high media values and high news values, especially now through social media; 2 ). As an icon to bring tourists directly by attending the event; 3 ). Motivate local people to develop creativity and be directly involved in tourism (Yoeti: 2000)

Shi and Zhang (2008) examine about Festival Experience: An Analysis of Value Dimensions, Perceived Value and Satisfaction. The research presented in this article focuses on customer perceived value and satisfaction in 
festival experinces, analysis what dimensions that customer value have and how value dimensions influence perceived value and visitor satisfaction. The study offers festival organizations increased sight into how to create customer values and how to select right value dimensions to form or maintain visitor satisfaction. Chatzinakos, G. (2016) also examine Exploring Potentials for Culinary Tourism through a Food Festival : The Case of Thessaloniki Food Festival di United Kingdom. This research seeks to conceptualize the way Thessaloniki promote culinary tourism, whilst supporting and building upon local networks, engaging and co-creating an urban experience with its citizens and visitors. The finding indicate that there is a lack of active participation by the locals and not enough communication among various assets that are associated with the culinary identity of the city.

Yoon and Uysal (2003) research an examination of the effects of motivation and satisfaction on destination loyalty : a structural model. This study offers an integrated approach to understanding tourist motivation and attempts to extend the theoretical and empirical evidence on the causal relationship among the pust and pull motivations, satisfaction and destination loyalty. The research model investigates the relevant relationships among the constructs by using a structural equation modelling approach. Consequently, destination manager should establish a higher tourist satisfaction level to create positive post-purchase tourist behavior, in order to improve and sustain destination competitiveness. Getz (2008) reviewed event tourism yaitu definition, evaluation, and research. This article reviews event tourism as both professional practice and a field of academic study. The origins and evaluation of research on event tourism are pinpointed through both chronological and thematic reviews. A conceptual model of the core phenomenon and key themes in event tourism studies is provided as a framework for spurring theoretical advancement, identifying management and tourism, and implications are drawn for advancing theory in event tourism.

Sanur as one of the famous tourism areas in Bali has tried to position culture, security, beauty and community and community base, through an event, namely the Sanur Village Festival (SVF). This annual activity was initiated by the Sanur community under the Sanur Development Foundation (YPS). This activity is coordinated with Indonesian tourism promotion activities, SVF 2018 supports Denpasar Sightseeing program 2018 and Wonderful Indonesia 2018. SVF was born after the Bali bombing tragedy in 2005, held for three days starting from 25-27 August 2006 at Maisonnette Inna Grand Bali Beach Sanur, Bali. SVF was conceived as a community-based activity, to raise the potential of tourism, art and culture and develop for the wider welfare of citizens. In the Opening of the 2018 SVF Ceremony, the Gowes application will also be launched, namely a bicycle service application from Boost, a digital economic platform owned by PT Axiata Digital Service Indonesia(YPS: 2018)

The 2018 SVF is one of the events included in the 2018 Top Ten Calendar of Events in Indonesia (Kemenpar: 2018). SVF 2018 is the 13th event with the sub theme of the activity, "Mandala Giri" which has inspired the journey of "The New Spirit of Heritage" which has been consistently since 2006 as SVF's fixed tagline. Mandala Giri which literally means circle and mountain. For Balinese people, the mountain represents the head, oriented to spirit and culture. The aim of SVF 2018 is 1). Re-branding Sanur as the main tourism area in Bali, 2). Improve the economy 
in Sanur based on tourism and creative economy, 3). Prepare a place for young people to display cultural creativity, art, music, etc., 4). Alternative tourism attractions during a visit to Bali, 5). Position Sanur in the world event calendar (YPS:2018)

In the development of a well-known destination with principle $3 \mathrm{~A}$ namely attraction, accessibility, and amenities. 3A for SVF 2018, in terms of attractions, SFV activities have environment-based activities, Balinese arts and cultural performances, festivals and exhibitions, various culinary and competitions, tourism discussions. Viewed from the aspect of accessibility or ease of reaching tourist destinations Sanur Beach can use the choice of airplane, can choose the destination of the flight to Ngurah Rai International Airport, Bali followed by a land trip to Sanur for araound 40 minutes from the airport. And in terms of its amenability in Sanur destinations there are many star and non star hotels including lodging or tourist huts (YPS:2018)

SVF 2018 activity programs are 1). Environmental activities are beach cleaning, coral reef planting, release of hatchlings, planting rare trees, 2). Festivals and exhibitions are traditional music and art performances, ornamental plant bazaars 3). Culinary namely Bali food festival, Heritage food, 4). Photography is a photo exhibition, photo competition, 5). Painting that is Painting on the spot, Body Painting, 6). Fun \& Sport activities are Bali International Triathlon, International Sanur Kite Festival, Fun Games, Sanur Golf Tournament, Jukung Race, Kids Zone, Village Cycling Tour (SVF:2018)

The target of visits for SVF since 2009-2017 as shown on table 1.2, has generally increased except in 2010, which decreased slightly from the previous year. SVF implementation dates from year to year around August, September or November with the location of Mertasari beach, Cottage Bali Beach, Maisonette Bali Beach and in 2018 located on Matahari Terbit Beach, Sanur Village. According to data from the Sanur Development Foundation (YPS: 2018) as the SVF committee, the target of tourist visits for the 2018 SVF is 155,400 tourists or an increase of $5 \%$ from the total visits in 2017 of 148,000.

Table 1.2

Event Sanur Village Festival

Year 2009-2017

\begin{tabular}{|c|c|c|c|c|c|c|c|c|c|c|}
\hline \multirow{2}{*}{ NO } & \multirow{2}{*}{ URAIAN } & \multicolumn{9}{|c|}{ TAHUN } \\
\hline & & 2009 & 2010 & 2011 & 2012 & 2013 & 2014 & 2015 & 2016 & 2017 \\
\hline 1 & Tanggal & 12.16 Agustus & 4-8 Agustus & $18-22 \mathrm{Nov}$ & $26-20$ Sept & 24.28 Sept & 20-24 Agustus & 26-30 Agustus & 24-28 Agustus & 9-13 Agustus \\
\hline \multirow{2}{*}{2} & \multirow{2}{*}{ Lokasi } & Pantai & Cottages Bali & Matahari & Maisonette & Maisonette & Maisonette Bali & Maisonette Bali & Maisonette Bali & Maisonette Bali \\
\hline & & Mertasari & Beach & Terbit & Bali Beach & Bali Beach & Beach & \begin{tabular}{|l|} 
Beach \\
\end{tabular} & Beach & \begin{tabular}{|l} 
Beach \\
\end{tabular} \\
\hline 3 & Jumlah Pengunjung & 15,000 & 15,000 & 20,000 & 50,000 & 80,000 & 135,000 & 142,000 & 144,000 & 148,000 \\
\hline 4 & Jumlah Transaksi Total & $2,800,000,000$ & $2,700,000,000 \mid$ & $5,400,000,000$ & $5,000,000,000$ & $8,000,000,000$ & $9,300,000,000$ & $10,250,000,000$ & $12,500,000,000$ & $14,700,000,000$ \\
\hline \multirow[t]{3}{*}{5} & Jumlah Peserta & & & & & & & & & \\
\hline & - Food Festival & 20 & 23 & 38 & 43 & 43 & 48 & 48 & 45 & 48 \\
\hline & - Bazar & 23 & 18 & 40 & 28 & 61 & 75 & 58 & 30 & 28 \\
\hline
\end{tabular}

Source : Yayasan Pembangunan Sanur (2018)

SVF as one of the major festivals in Bali, plays a role in preserving cultural and culinary arts attractions in the Municipality of Denpasar, especially in Sanur Village. In addition, SVF also contributes in promoting tourism objects with various booths in which there are culinary and creative SMEs. The 2018 SVF also plays a role in attracting tourists to Denpasar City, especially the Sanur area, which can be seen from foreign and domestic tourists visiting before and after the event. With the various empirical studies above, the 2018 SVF event will further enhance the image 
of Indonesian tourism as a quality tourism destination, thus attracting tourists from both foreign and domestic tourists and the SVF is expected to be able to show more interesting attractions and creativity in the future.

The purpose of this study was to determine the level of visitor satisfaction attending the Festival in Bali, a case study on SVF 2018. While the specific objectives of this study were: to determine the factors and variables that most influence determining visitor satisfaction attending SVF 2018. Data analysis techniques in this study using quantitative methods with parametric statistical analysis namely confirmatory factor analysis. Measurement of visitor satisfaction level in this study uses Crompton's (2003) theory model with 6 elements of satisfaction, namely Convenience Value, Service Value, Preceived Price, Aesthetic Value, Playful Value, Social Value. The total variables analyzed are 26 variables. The completion of this factor analysis was carried out with the help of the SPSS 17.00 program. The sequence of analysis was tested for validity and reliability, then followed by a feasibility study of factor formation consisting of KMO and Bartlett's Test, Communalities, Total Variance Explained, Component Matrix, Component Score Coefficient Matrix.

\section{METHODOLOGY}

This research is a quantitative research, because it uses statistical analysis namely factor analysis using the Statistical Package for Social Science (SPSS) 17.0 for Windows program. This study uses a confirmatory factor analysis model based on the theoretical concept of Crumpton (2003). There are 6 factors and 26 variables in this study namely Convenience Value ( 5 variables), Service Value (6 variables), Preceived Price (4 variables), Aesthetic Value (4 variables), Playful Value (4 variables), Social Value (3 variables ). Based on this theory, factor analysis will find its role in determining visitor satisfaction in attending SVF 2018. Then the factor analysis used in this study will be supported by qualitative descriptive analysis. The approach used is a quantitative and qualitative approach. This approach is expected to help researchers to examine the variables of the phenomenon under empirical study.

The location of this research was conducted at the SVF 2018 location, namely the Sunrise Beach, and other locations in Sanur Village, Denpasar-Bali. There were 5 locations selected for distributing the research questionnaire for 3 days, on 22nd, 24th, 26th September 2018 namely Matahari Terbit Beach, Griya Santrian Art Gallery, Segara Beach, Retro Resto Sanur, Jalan Bali Hyatt in Sanur Village. Respondents in this study were visitors to the 2018 SVF with a total of 135 people. The sampling technique used in this study is non-probability sampling with the accidental sampling method. Kusmayadi and Sugiarto (2000) explained that sampling using non-probability sampling made it impossible for someone to become a respondent. Accidental sampling technique is used without careful planning. Respondents asked for information were actually obtained by chance without any particular consideration. By using this method respondents who respond are determined by chance. For the purposes of data analysis using factor analysis, Sugiyono (2003) suggests that the sample size (n) in factor analysis is at least four or five times the number of variables. 
There are two types of data in this study, qualitative data and quantitative data. Qualitative data was obtained based on various information from interviews and the results of filling in questionnaires by SVF 2018 visitors. Quantitative data are data in the form of numbers such as the number of visits to SVF, data on respondents' characteristics during the study, and other data related to the research. While the data sources used in this study are primary data, namely, in the form of data obtained directly through the research process, the results of visitor questionnaires, as well as data obtained from several related parties such as the opinions of experts. And secondary data, which is sourced from the Bali Provincial Statistics Agency (BPS), satisfaction and festival journals, as well as some literature relating to research titles.

\section{RESULTS AND DISCUSSION}

The Data has a very important role for a study because the data is a description of the variables studied and functions as a tool to prove the hypothesis. Therefore, data in a study can be collected with an instrument. The instrument used in collecting data must fulfill two important requirements, namely the validity and reliability that must be tested. Validity test can be carried out extensively by test retest or by testing the same instrument in several respondents. If the value of $\mathrm{Ri}$ is $>0.3$, then the instrument can be declared valid and can be used in future research (Antara: 2017). The test results of the validity of the questions used in this study. This validity test used 33 respondents studied $(\mathrm{N}=33) .33$ of these people are considered to have been normally distributed. And validity test results in this study indicate an interval of 0.323 to 0.662 , which means that the research instrument has fulfilled the validity requirements with the item-total correlation coefficient value each greater than $0.3(\mathrm{Ri}>0.3)$. Thus a valid or valid research instrument is used as a data collector. While the reliability test results indicate the extent to which a measuring instrument can be trusted or can be relied upon to retrieve data. Reliability test was carried out by alpha-Cronbanch variance test. If the alphaCronbach value is $>0.6$; then the instrument is declared valid and can be used in research. The results of the instrument reliability test in this study, the alpha coefficient is 0.802 . With an alpha-cronbach value of $0.802>0.6$, this research instrument can be trusted, reliable and accurate as a data collector.

\section{Respondents Characteristic}

This study uses the opinions of SVF 2018 visitors with a total of 135 sheets of questionnaires during the study period. A description of the characteristics of the respondent in this case are group of nationality, gender, age, and position. Based on nationality, the largest number of participants came from Indonesia ( 75 peoples/55.56\%), while the smallest number came from the continent of Africa (4 peoples/3.70\%). Other countries include: Australia, England, France, Germany, Italy, Spain, Japan, Malaysia, Thailand, Singapore, Japan, Korea and India. The majority of Indonesian nationalities come from Jakarta and Surabaya. According to the sex group most of them are (85 peoples/62.96\%) while the rest are women (50 peoples/37.3\%). Based on the age group, the highest number of participants were 
at the age of 20-30 years (47 peoples/34.81\%), followed by 30-40 years old (40 peoples/29.63\%), aged 5-20 years (21 peoples/15.56\%), aged 40 to 50 years (15 people/11.11\%), and the age of 50 years (5 peoples/3.70\%). These results illustrate that the majority of SVF 2018 visitors are young people who have the desire and motivation to enjoy a pleasant experience during the Festival. From the respondents selected based on their position, it shows that the highest number of respondents is employee (66 peoples/48.89\%), students (40 peoples/29.63\%), entrepreuners (14 peoples/10.37\%), lecturer ( 8 peoples/5.92\%), and manager (7 peoples/5.18\%). Uneven distribution in these five locations is due to very limited conditions and time

\section{FACTOR ANALYSIS}

In this study partial factor analysis was conducted in which each analysis used confirmatory factor analysis of the constituent items of each factor as many as six factors. Then the six factors were coded, namely F1 for Convenience Value factor, F2 for Service Value factor, F3 for Perceived Price factor, F4 for Aesthetic Value factor, F5 for Playful Value factor and F5 for Social Value factor.

\section{F1. Convenience Value Factor}

The result of analysis the Convenience Value (F1) factor is the result of a combined analysis of five variables, namely X1 (transportation and parking facilities); X2 (food and beverage choices); X3 (shopping and other facilities); X4 (signage of venue); and X5 (information received). After processing the data for F1 factor, the KMO value of 0.697 is obtained which means $\mathrm{KMO}>0.5$ and with a value of $\operatorname{Sig}<0.000$. It means that all observed variables are worthy of factoring (Tenaya, 2002). Percentage of the role of each constituent variable in the factor forming $\mathrm{F} 1$ factor which can be explained by the factors formed, such as variable $\mathrm{X} 1$ is $70.4 \%$; variable $\mathrm{X} 2$ is $65.9 \%$; variable $\mathrm{X} 3$ is $73.4 \%$; variable $\mathrm{X} 4$ is $65.4 \%$; and the variable $\mathrm{X} 5$ is $60.8 \%$. The highest role in the formation of factor F1 lies in the variable X3 and the smallest role is variables X5. The eigenvalue and the factor F1 matrix component state that F1 factor can represent its constituent component of $33.878 \%$ of the total variance, which means that a factor is formed representing five variables X1 to X5 with initial eigenvalues of 2.710 greater than 1,00 . Then the results of the matrix component analysis show the closeness of the relationship or correlation of each variable of X1 to X5 that composes the F1 factor. The higher the value of the matrix component of each variable, the stronger the variable relationship or the greater the role in the formation of factors, and vice versa. The result is the $\mathrm{X} 3$ variable has the strongest relationship to $\mathrm{F} 1$ factor with a correlation coefficient of 0.728 and the weakest relationship is variable X5 with a correlation coefficient of 0.200 .

\section{F2. Service Value Factor}

The result of analysis of the Service Value (F2) factor is the result of a combined analysis of six variables, namely X6 (reliable and consistent of service), X7 (neat and clean), X8 (willing to help visitor), X9 (timely service), X10 (courteous and polite) and X11 (security of venue). After processing the data 
obtained the KMO value is 0.500 (the terms $\mathrm{KMO}$ value is equal to or $>0.05$ ) and the significance value (Sig.) Is 0.000 which means that all observed variables are worthy of factoring. The percentage of the role of each constituent variable in the factor forming F2 factor can be explained by the factors formed, such as variable $\mathrm{X} 6$ is $58.0 \%$; variable $\mathrm{X} 7$ is $60.7 \%$, variable $\mathrm{X} 8$ is $51.8 \%$, variable $\mathrm{X} 9$ is $55.0 \%$, variable $\mathrm{X} 10$ is $56.4 \%$ and variable $\mathrm{X} 11$ is $57.3 \%$. From these results $\mathrm{X} 7$ has the highest role in the formation of F2 factors that and the smallest role is X8. The Eigenvalue and the factor matrix components F2 state that F2 factor can represent its constituent component of $29.451 \%$ of the total variance, which means that a factor representing six variables is $\mathrm{X} 6$ to $\mathrm{X} 11$, with an initial eigenvalues of 1.178 greater than 1.00. The results of the matrix component analysis indicate the closeness of the relationship or correlation of each variable from X6 to X11 that composes the F2 factor. From the results of this analysis, it can be seen that the variable $\mathrm{X} 7$ has the strongest relationship to $\mathrm{F} 2$ factor with a correlation coefficient of 0.612 and the weakest relationship is the variable $\mathrm{X} 8$ with a correlation coefficient of 0.303 .

\section{F3. Perceived Price Factor}

The result analysis of the Perceived Price (F3) factor is the result of a combined analysis of four observed variables, namely X12 (price for entry); X13 (food and beverage charge); X14 (transportation charge); and X15 (price for good). After processing the data obtained KMO value of 0.513 means $\mathrm{KMO}>0.5$ and with a value of Sig $<0.000$, which means that all observed variables are worthy of factoring. Percentage of the role of each constituent variable factor in forming F3 factor which can be explained by the factors formed, such as variable X12 is $66.2 \%$; variable X13 is $59.2 \%$; X14 variable is $36,3 \%$; and the X15 variable is $47.7 \%$. Variables X12 have the highest role in the formation of F3 factor and the smallest role is X15. Eigenvalue values and Factor Matrix Components F3 state that F3 factor can represent its constituent component by $31.613 \%$ of total variance, which means that a factor is formed representing four variables X12 to X16, with initial eigenvalues of 1.265 greater than 1.00 . The results of the matrix component analysis show the closeness of the relationship or correlation of each variable of the $\mathrm{X} 12$ to X16 that composes the F3 factor. The result is the variable X12 has the strongest relationship to the F3 factor with a correlation coefficient of 0.760 , and the weakest relationship is the variable X15 with a correlation coefficient of 0.180 .

\section{F4. Aesthetic Value Factor}

The result analysis of Aesthetic Value (F4) Factor is the result of a combined analysis of four variables, namely X16 (festival ambience), X17 (beautiful scenery), X18 (elegant stage arrangement), and X19 (fine festival program). After processing the data obtained KMO value of 0.547 means $\mathrm{KMO}>$ 0.5 and with a value of Sig $<0,000$ means that all observed variables are worthy of factoring. Percentage of the role of each constituent variable factor in forming F4 factor which can be explained by the factors formed, such as the variable X16 is $46.1 \%$; variable $\mathrm{X} 17$ is $61,4 \%$, variable $\mathrm{X} 18$ is $48.7 \%$ and variable $\mathrm{X} 19$ is $55.6 \%$. From these results the variable X17 has the highest role in the formation of F4 factor and the smallest role is X19. Eigenvalue and Factor Matrix Components F4 state 
that F4 factor can represent its constituent component by $31.225 \%$ of total variance, which means that a factor is formed representing four variables X16 to X19, with initial eigenvalues of 1.249 greater than 1.00 . The results of the matrix component analysis show the closeness of the relationship or correlation of each variable of X16 to X19 that composes the F4 factor. The result is the variable X17 has the strongest relationship to F4 factor with a correlation coefficient of 0.682 and the weakest relationship is the variable X19 with a correlation coefficient of 0.095 .

\section{F5. Playful Value Factor}

The result analysis of the Playful Value (F5) factor is the result of a combined analysis of four variables, namely X20 (pleasure of the journey); X21 (enjoyable); X22 (relaxing); and X23 (excited). After processing the data obtained $\mathrm{KMO}$ value of 0.502 means $\mathrm{KMO}>0.5$ and with a value of Sig $<0.000$, which means that all observed variables are worthy of factoring. The percentage of the role of each constituent variable in the factor forming F5 factor can be explained by the factors formed, such as the variable X20 is $76.9 \%$; variable X21 is $94,6 \%$; X22 variable is $37.4 \%$; and the $\mathrm{X} 23$ variable is $62.3 \%$. It turns out that the $\mathrm{X} 20$ variable has the highest role in the formation of F5 factors, and the smallest role is X22. Eigenvalue values and F5 Matrix Components state that F5 factor can represent its constituent component by $33,337 \%$ of total variance, which means that a factor is formed representing four variables X20 to X23, with initial eigenvalues of 1.333 greater than 1,00 . The results of the matrix component analysis, which shows the closeness of the relationship or correlation of each variable of X20 to X23 that composes the F5 factor. The variable X20 has the strongest relationship to F5 factor with a correlation coefficient of 0.761 , and the weakest relationship is the X22 variable with a correlation coefficient of 0.420 .

\section{F6. Social Value Factor}

The result of the analysis of Social Value (F6) factor is the result of a combined analysis of three variables, namely X24 (other's interesting); X25 (enriching knowledge) and X26 (making friends). After processing the data obtained KMO value of 0.502 means $\mathrm{KMO}>0.5$ and with a value of $\mathrm{Sig}<0.000$, which means that all observed variables are worthy of factoring. The percentage of the role of each of the constituent variables in the factor forming F6 factor can be explained by the factors formed, such as the variable X24 is $76.9 \%$; variable X25 is $61.4 \%$ and variable $\mathrm{X} 26$ is $37.4 \%$. It turns out that the X25 variable has the highest role in the formation of F6 factor, and the smallest role is X24. The Eigenvalue and F6 Matrix Components state that factor F6 can represent its constituent component by $33,337 \%$ of the total variance, meaning that a factor is formed representing 3 variables X24 to X26, with initial eigenvalues of 1.333 greater than 1,00 . The results of the matrix component analysis, which shows the closeness of the relationship or correlation of each variable of X24 to X26 that composes the F6 factor. The X25 variable has the strongest relationship to F6 factor with a correlation coefficient of 0.761 , and the weakest relationship is the variable X24 with a correlation coefficient of 0.420 .

The results of this study indicate: the analysis of the role of variables on the forming factors obtained by the variable X21 (enjoyable) has the highest role 
and the variable X 14 (transportation charge) has the lowest role. Recapitulation of factor analysis obtained the results of playfull value (F5) has the highest role and perceived price factor (F3) has the lowest role of the overall factor value. The SVF 2018 committee, the Sanur Development Foundation (YPS) already has standards in carrying out SVF activities from the first to the 13th in 2018. Many parties are involved in supporting this festival and are very important in implementing the standards that have been made. With the recognition of the most important factors and variables that determine visitor satisfaction during the SVF 2018, the implication of the strategy as an operational form that can be carried out by the SVF 2018 committee is to further improve the standard types of products offered, in accordance with the characteristics of Balinese culture-oriented areas such as: standard facilities, services, procedures, fees, provisions for employees who work and skills qualifications for all parties who support the SVF event. Increasing the standard of Festival products and the ability of human resources who work in them can always be done before the event takes place, making visitors more sensitive when SVF can be improved. The role of the central and regional governments is also very helpful in supporting tourism activities. This program is a lot of programs to achieve quality human resources in fields that can be carried out well and in future activities.

\section{Conclusions}

The results of the factor analysis and visitor comments attending the 2018 SVF festival show that the overall dimensions of satisfaction are Convenience Value, Service Value, Preceived Price, Aesthetic Value, Playful Value, and Social Values play a real role in visitor satisfaction attending a festival in Bali, a case study on SVF 2018. Judging from the dimensions that most influence SVF 2018 visitor satisfaction is a playful value factor formed by four variables. While the variable that has the most role in determining SVF 2018 visitor satisfaction is the X21 (enjoyable) variable. In general, visitor satisfaction attending the 2018 SVF has been very good. This is indicated by the opinion that most visitors strongly agree / are very satisfied, and only a small percentage stated that they agreed enough / were satisfied with the indicators of dimensions of visitor satisfaction attending SVF 2018 during the study period.

\section{References}

Anonim. 2018. Badan Pusat Statistika: Data Kunjungan Wisatawan Mancanegara dan Nusantara yang Langsung Datang ke Bali. Laporan BPS Provinsi Bali.

Antara, M. 2017. Metodologi Penelitian. Modul Metodologi Penelitian Pascasarjana (Materi Kuliah). Universitas Udayana.

Chatzinakos.G.2016. Exploring Potentials for Culinary Tourism trough a Food Festival : The case of Thessaloniki Food Festival. Transnational Marketing Journal. Transnational Press London. 
Getz, D. 2008. Event Tourism : Definition, Evolution, and Research. Progress in Tourism Management. Tourism Management 29, 403-428. Elsevier, Ltd.

Kusmayadi dan Sugiarto, E. 2000. Metodologi Penelitian Dalam Bidang Kepariwisataan. Jakarta: PT. Gramedia Pustaka Utama

Paggiaro, A. and Mason, C, M. 2012. Investigating the Role of Festivalscape in Culinary Tourism : The Case of Food and Wine Events. Tourism Management 33 (1329-1336). Elsevier Ltd.

Smith. S. 2007. Analysis of Tourists Attending a Culinary Event : Motivations, Satisfaction and Behavioral Outcomes. University of Tenessee, Knoxville. Trace : Tenessee Research and Creative Exchange.

Sugiyono.2003. Statistika untuk Penelitian. Alfabeta, Bandung

Tenaya, IM. Narka.2002. Kuantivikasi data Kualitatif dengan metode MSI (Metode Suksesif Interval-MSI) Laboratorium Statistika. Fakultas Pertanian. Universitas Udayana

Yayasan Pembangunan Sanur. 2018. Data Realisasi Event Sanur Village Festival periode tahun 2009-2017. Meeting Action Plan Summary (MAPS) Sanur Village Festival 2018.

Yoeti, Oka A.2000. Manajemen Wisata Konvensi. Jakarta: PT. Pertja

Yoon and Uysal. 2003. An Examination of the effects of Motivation and Satisfaction on Destination Loyalty: a Structural Model. Tourism Managemen. Elsevier

Zhang, T and Shi, Y. 2008. The Festival Experience: An Analysis of Value Dimensions, Perceived Value and Satisfaction. https://www.researchgate.net/ publication/251865698 